\title{
Richard B. Freeman, Peter Boxhall and Peter Haynes (eds): What Workers Say: Employee Voice in the Anglo-American Workplace
}

\author{
Cornell University Press, Ithaca and London, 2007, 244 pp
}

\author{
Michael Doherty
}

Published online: 13 February 2010

(C) Springer Science+Business Media, LLC 2010

The issue of employee "voice" at work is one in which there has been an explosion of interest in recent years amongst researchers, policy-makers and labor market actors alike. Some of the resulting literature has focused on the economic and business rationale for giving workers greater say at their organizations, while other studies have looked at the matter in the context of general explorations of the state of democracy and social capital in the contemporary world. Undoubtedly, though, a large amount of interest in this topic stems from the recognition of the continuing decline in the presence, and organizational strength, of trade unions at workplaces, particularly in the Anglo-American world. Many of these themes have collided in events (often widely covered in the general media) like the so-called 'Rice Krispy' redundancies in the UK, where workers learned for the first time that they were to be made redundant by listening to the morning radio or watching breakfast television. The violation of human dignity involved, the appalling lack of worker-management communication and breach of the trust inherent in the employer-employee relationship, as well as the absence, or, where they were involved, seeming impotence, of trade unions in these (and similar) instances has led to an increased focus on ways of tempering the excesses of the Anglo-American capitalist model, by promoting employee representative voice and participation at work.

This collection reviews the current state of play in six Anglo-American countriesthe United States, Canada, the United Kingdom, Ireland, Australia and New Zealandby identifying what workers seek in terms of voice at work and assessing the extent to which the relevant labor institutions deliver that voice. Noting that the countries in question have common historical lineages (in terms of political and legal structures), are generally more "market-friendly" with relatively small governments compared with other (especially Continental European) advanced capitalist economies, and share a number of labor market outcomes and institutional patterns (importantly, for example, in

\footnotetext{
M. Doherty $(\bowtie)$

Dublin City University, Dublin, Ireland

e-mail: michael.doherty@dcu.ie
} 
terms of unionization and collective bargaining trends), the editors argue that strong possibilities for mutual learning and policy adaptation exist.

The book is organized in two parts. First, the country studies (grouped into three sets of geographic pairs) are presented. In the second part, the book turns to crosscountry analysis, looking, respectively, at the common themes and lessons for trade unions, employers and the governments, and concluding by summarizing the overall picture of the national studies.

Each country chapter follows a similar outline by describing the historical and institutional employment relations context, outlining the voice possibilities open to workers, examining (through the use of extensive examination of national data sets) what workers say they want or need in terms of voice, and concluding by examining the present and future role of the labor market actors (unions, employers and governments) in the delivery of voice mechanisms. In these chapters the similarities come across quite clearly (the almost universal decline in trade union density; the "representation gap" between the voice options workers have and those that they desire), but so too do the divergences, particularly within the geographic groupings (for example, while the US Wagner Act outlawed non-union institutions of voice, Canadian law permits employees dealing with management independently of unions; while the UK unions faced a legislative onslaught in the 1980s and 1990s, the Irish unions negotiated national "social partnership" agreements). In this way, the objective of presenting lessons of good (and bad!) practice from which policy options can be distilled is comprehensively achieved.

A number of major themes result from the analysis of the national data. In all countries, a representation gap does exist (up to one-third of workers in non-union firms in the UK, New Zealand and Australia, for example, expressed frustrated demand for union representation). Worryingly, it those workers who objectively seem to be in greatest need of collective labor protection (young workers, lowerincome workers and workers who report many problems at their workplace) who are most likely to be frustrated. What a number of the studies show is that union membership is highly experiential; those most positive about union membership tend to be exposed to unions directly or indirectly (via family members, friends etc). The primary challenge for the unions outlined by these studies is how to "get at" young workers, increasing their exposure to unions and opportunities to join (this is vital as the authors note that, contrary to the orthodox "wisdom" that young workers are more individualistic, such workers report a large representation gap). In terms of non-members in workplaces where unions do organize, further challenges present themselves. The national studies show that "free-riding" is a large problem in the countries where union membership is voluntary (the UK, Ireland, Australia and New Zealand). This partly relates to the financial cost of membership, but also to a view that unions do not always deal with matters of concern in the modern workplace (the UK and Ireland chapters demonstrate how issues of promotion and training, for example, are ones unions are felt not to adequately address). Most of the studies also show that the attitude of employers is crucial to decisions on whether or not to join the union. The virulently anti-union atmosphere in the US is well-known, but it is stark that in Ireland, for example, significant numbers report they would not join a union "for fear of damaging their career prospects" (interestingly, however, in the Antipodean countries (Australia and New Zealand), employers have not taken a 
particularly anti-union approach, but density has still declined, illustrating the multifaceted nature of the conundrum for unions).

The book is not, however, simply a study of union representation, as the editors explicitly seek to consider non-union voice in the six countries. Here, the data again throws up some fascinating (often counter-intuitive findings). The overwhelming message from the studies is that workers generally prefer a mix of union and nonunion, direct and indirect, voice mechanisms. Hence, the principal argument of the editors is for the promotion (by all labor market actors) of a range of forms of employee representation based on employee choice. In addition to being the favored choice of the workers sampled here, such an approach has the benefits for employers of seeming to deliver the best outcomes in terms of minimizing conflict and resolving grievances at the workplace (which, the studies show, have certainly not gone away, despite the rhetoric of Human Resource Management advocates). For unions, who often fear substitution by non-union voice structures, the country studies show that union presence at the workplace is generally complemented by these, as long as they are genuine voice mechanisms, populated by independent employees, and not merely "sham" management vehicles. The studies overwhelmingly show that workers favor representative structures that foster co-operation, but, crucially, not compliance, with management. For unions and governments, promoting a system of employee voice based on diversity and flexibility (allowing for differences in sector, workforce composition etc) has the added plus of giving the workers what they say they want!

Despite the acknowledged intention to focus on union and non-union voice mechanisms, it is in the latter area that the book is weaker. A more comprehensive and careful explanation of what existing or prospective non-union voice or representation structures entail, and how they do, or might, operate would have been useful (this is provided in the chapter on Ireland). In the UK, for example, it would not be common to describe statutory protection against unfair dismissal as non-union voice, but it is so-described in the chapter on Canada. As a result, there is a slight impression of union voice being compared to a rather ill-defined "something else". This is, however, a minor quibble with what is, overall, a fascinating, wellresearched and highly informative collection that provides plenty of food for thought for researchers and policy-makers alike. 